\title{
ScDNA-DNA hybridization studies in Pacific and Caribbean isolates of Dictyosphaeria cavernosa (Chlorophyta) indicate a long divergence
}

\author{
J. L. Olsen*, W. T. Stam, P. V. M. Bot \& C. van den Hoek \\ Department of Marine Biology, Biology Centre, University of Groningen; P. O. Box 14, \\ NL-9750 AA Haren (Gn), The Netherlands
}

\begin{abstract}
Genomic size and complexity were calculated for the pantropical chlorophyte, Dictyosphaeria cavernosa (Cladophorales). Genome characterization of the Hawaiian material by means of DNA renaturation studies showed highly repetitive $(31.3 \%)$, middle repetitive $(42.7 \%)$, and singlecopy $(25.8 \%)$ fractions; and an estimated haploid genome size of $1.79 \mathrm{pg}$ DNA. A G:C content of $43 \%$ was calculated from a melting curve of DNA. Pacific and Caribbean isolates of this species were compared using single-copy nuclear DNA-DNA hybridization. Results show a relatively low thermal stability of the hybridized DNA $\left(\triangle \operatorname{Tm}(e)=10^{\circ} \mathrm{C}\right)$ which suggests that these Pacific and Caribbean lineages may have been separated for up to $55 \mathrm{Ma}$.
\end{abstract}

\section{INTRODUCTION}

Levels of genetic divergence among widely disjunct isolates of morphologically indistinguishable species is a central area of interest in understanding species evolution and distribution patterns in the context of historical biogeography. The use of single-copy (sc) nuclear DNA-DNA hybridization measurements on isolates of putatively the same species and "closely" related species, collected from widely differing geographic localities, provides a distance measure of DNA sequence homology that can help to elucidate some of these puzzles. In this research note we present data on size and complexity of the genome, and provide a preliminary estimate of divergence time between Pacific and Caribbean isolates of the tropical chlorophyte, Dictyosphaeria cavernosa (Forssk.) Børgesen.

\section{MATERIALS AND METHODS}

Extensive theoretical discussions of single-copy DNA-DNA hybridization principles and methods can be found in Bonner et al. (1973) and Britten et al. (1974). In brief, by measuring the renaturation rate of complementary sequences, the total DNA content of the haploid genome, as well as the proportion of repetitive and single-copy DNA can be calculated. Subsequent comparisons of homologous and heterologous reassociations

\footnotetext{
- Present address: Department of Botany, LSB-2017, University of California, Berkeley, CA 94720 USA
} 
within and among species provides a measure of genetic divergence reflected by two parameters. These are percent relative binding (RB\%) and thermal stability of the hybrids as measured by the thermal midpoint of elution $\left[\operatorname{Tm}(e){ }^{\circ} \mathrm{C}\right]$.

Protocols used in this research are briefly summarized here following Bot (personal communication) and Stam et al. (1988, in preparation).

$\mathrm{S}$ p e c i m e n s. Specimens of Dictyosphaeria cavernosa were collected from Coconut Island, Oahu, Hawaii and Boiler Bay, St. Croix, U.S.V.I. Dictyosphaeria versluysii was collected from Waikiki, Oahu, Hawaii. Only young, clean thalli were selected. Further cleaning consisted of epidermal peels and removal of chunks of unexposed thallus. Tissue was further examined with the DNA fluorescent stain, DAPI, to screen for bacterial and cyanophytic contaminants. Only material passing this test was finally considered acceptable for DNA extraction. Samples were frozen at $-20^{\circ} \mathrm{C}$. Most of the material was subsequently lyophilized for transport prior to DNA extraction. We caution that, while axenic material is always preferred, field-collected material can be used if care is taken. Comparative experiments have been conducted in our laboratory with cleaned, fieldcollected material and cultured species of Cladophora. Although cultured material gave a homologous hybridization of up to $10 \%$ higher, overall results were favorable. Fieldcollected Laminaria species have also been successfully used.

DNA extraction and purification. Fresh or lyophilized algal tissue was pulverized in liquid nitrogen and lysed at $50^{\circ} \mathrm{C}$ for $2 \mathrm{~h}$. The lysis buffer consisted of TE $(100: 50)$ plus $1 \%$ SDS and $1 \mathrm{M}$ sodium perchlorate, $\mathrm{pH}=8.0$. From the lysate, DNA was purified by deproteinization with phenol-chloroform followed by chloroform-isoamyl alcohol treatments and then, two ultracentrifugation runs on $\mathrm{CsCl}$ gradients in the presence of ethidium bromide. Incubation with RNase and pronase was performed between ultracentrifugations. DNA concentration and purity were monitored spectrophotometrically. DNA was sheared to ca $450 \mathrm{bp}$ fragments by sonication. The length of the sheared fragments was measured electrophoretically against markers of known length.

Genome characterization. A Cot [DNA concentration (mol nucleotides) $\times$ time] curve was determined for $D$. cavernosa (Hawaii) from which genetic complexity, an estimate of genome size and conditions necessary for single-copy DNA isolation could be calculated (Stam et al., 1988 in prep). G:C content was calculated from a melting curve of total unsheared DNA in $0.1 \mathrm{SSC}$ buffer in order to determine incubation temperature for hybridization (Mandel \& Marmur, 1968).

H y b r id i z a ti on s. The Hawaiian D. cavernosa was used as the tracer. One part of ${ }^{3} \mathrm{H}$-gap-labeled, single-copy tracer DNA was mixed with 2000 parts of total driver DNA. The mixture was denatured, allowed to reassociate to Cot 20000 at $25^{\circ} \mathrm{C}$ below the melting temperature of native DNA. The reaction was stopped in $-20^{\circ} \mathrm{C} \mathrm{EtOH}$.

Chromatography. Reassociated DNA was subjected to hydroxylapatite chromatography. Single stranded (ss) DNA was removed at $60^{\circ} \mathrm{C}$, whereas double stranded (ds) DNA was subjected to stepwise thermal elution $\left(65-95^{\circ} \mathrm{C}\right)$.

Relative binding and thermal stability. Radioactivity in the ds fraction relative to the total (dsDNA + ssDNA) gives the renaturation for each hybrid. Renaturation rate of a heterologous comparison relative to the homologous one gives relative binding ( $\mathrm{RB} \%)$, a measure of sequence homology. The extent to which this parameter reflects genotypic difference is a function of true sequence mismatch and/or deletions in 
the genome. The difference in thermal stability between homoduplexes and heteroduplexes was determined from the thermal elution profiles. The temperature at which $50 \%$ of the hybrids were eluted is also a measure of genotypic relationship.

Divergence $\mathrm{t}$ im e. It is estimated that $1^{\circ} \mathrm{C} \triangle \mathrm{Tm}(\mathrm{e})$ equals an average of $5.5 \mathrm{Ma}$ of elapsed time. This is based on the assumption that DNA sequences evolve in a clocklike manner (cf. Wilson et al., 1977; Ayala, 1986 for thoughtful discussions); that $1^{\circ} \mathrm{C}$ $\Delta \operatorname{Tm}(\mathrm{e})=1 \%$ mismatch (Bonner et al., 1973) $=0.5 \%$ average sequence change per genome; that $\triangle \operatorname{Tm}(e) / 2=$ the average sequence change per genome $=$ rate of sequence change $\times$ divergence time; and that an average rate of sequence change of $0.09 \% / \mathrm{Ma}$ is accepted (Stam et al., 1988, in prep.)

\section{RESULTS}

Reassociation kinetics analysis of Dictyosphaeria cavernosa shows that $31.27 \%$ of the DNA is highly repetitive, $42.47 \%$ is middle repetitive and $25.8 \%$ behaved as a kinetic class consistent with that predicted for single copy sequences (Fig. 1). The haploid

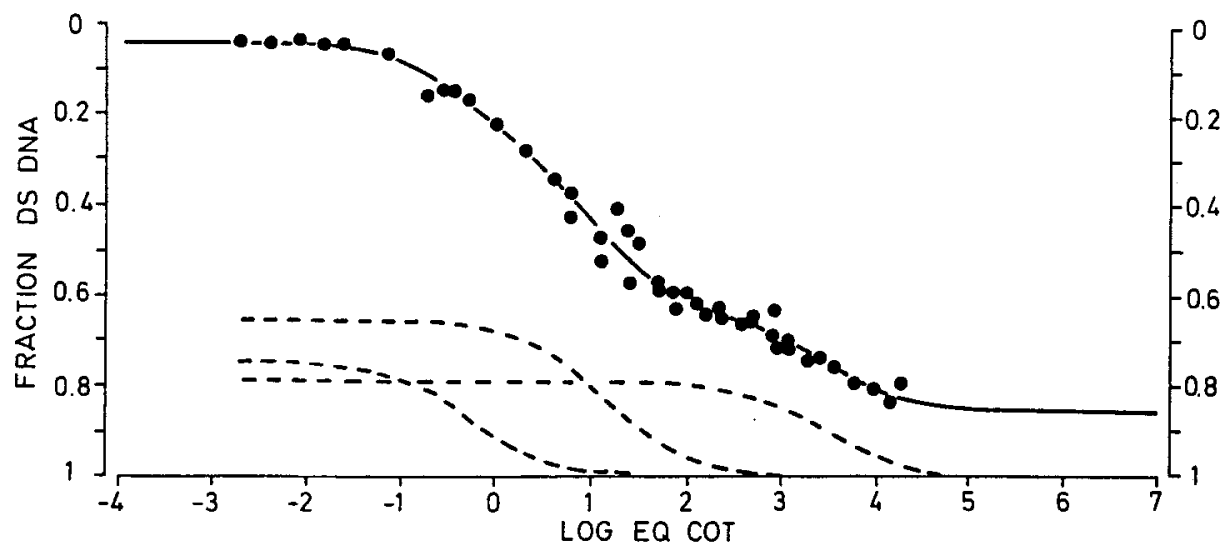

Fig. 1. Reassociation of Dictyosphaeria cavernosa (Coconut I., Oahu, Hawaii). The solid line represents the best least squares fit of the data to three second-order reassociation components. Dashed lines represent the highly repetitive, middle repetitive and single-copy fractions, respectively. Root mean square of the fit was 0.026 . Reassociation was carried out over a concentration range of $25-4000 \mu \mathrm{g} / \mathrm{ml}$, in phosphate buffer molarities ranging from $0.03-0.36$, incubation times $0.5-96 \mathrm{~h}$, and a temperature of $60^{\circ} \mathrm{C}(25,100,1000$ and $2000 \mu \mathrm{g} / \mathrm{ml}$ series $)$ and $67^{\circ} \mathrm{C}(4000 \mu / \mathrm{ml}$ series $)$

genome size is estimated at $1.79 \mathrm{pg}$ DNA. A melting temperature of $72{ }^{\circ} \mathrm{C}$ was determined on total unsheared DNA from which the G:C content was calculated to be $43 \%$. Other technical parameters are summarized in Table 1.

D. cavernosa from Coconut I, Oahu, Hawaii was used as the radioactive tracer to which the Caribbean isolate and other species were hybridized. Results are given in Table 2 and the relationships summarized in Figure 2. These data show that disjunct isolates of $D$. cavernosa from Hawaii and St. Croix are genetically very divergent, a finding that supports earlier protein immunological distance measurements on isolates from the same localities (Olsen-Stojkovich et al., 1986). D. versluysii is even more distant, 
Table 1. Kinetic analysis of total DNA from Dictyosphaeria cavernosa (Coconut Island, Oahu, Hawaii) from Figure 1

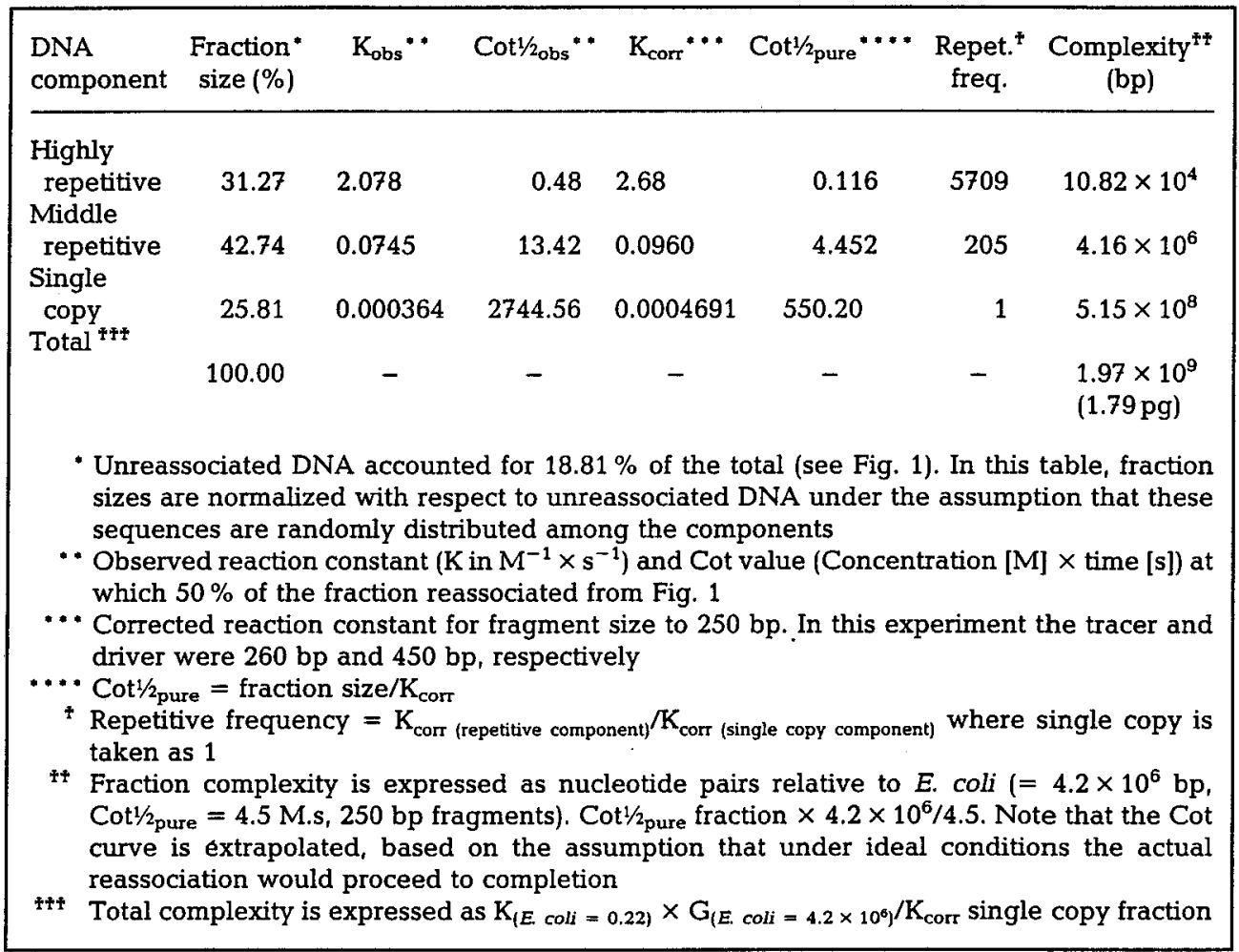

Table 2. Summary of hybridization results, based on relative binding ( $R B \%)$ and on differences in thermal stability, i. e. thermal midpoint of elution $\left[\triangle \operatorname{Tm}(\mathrm{e}){ }^{\circ} \mathrm{C}\right]$, from 150 -bp fragments of $D$. cavernosa scDNA tracer and 450 -bp fragments of total DNA drivers

\begin{tabular}{|c|c|c|c|c|}
\hline Species & Status & $\underset{\left({ }^{\circ} \mathrm{C}\right)}{\Delta \operatorname{Tm}(\mathrm{e})}$ & $\begin{array}{l}\mathrm{RB} \\
(\%)\end{array}$ & $\begin{array}{c}\text { Hypothesized } \\
\text { divergence (Ma) }\end{array}$ \\
\hline $\begin{array}{l}\text { Dictyosphaeria cavernosa } \\
\text { (Coconut I., Oahu, Hawaii) }\end{array}$ & tracer & $0^{*}$ & $100 \cdots$ & \\
\hline $\begin{array}{l}\text { Dictyosphaeria cavernosa } \\
\text { (Boiler Bay, St. Croix, U.S.V.I) }\end{array}$ & driver & $\begin{array}{c}10.0 \\
(+/-0.6)\end{array}$ & $\begin{array}{c}13.9 \\
(+/-0.8)\end{array}$ & 55 \\
\hline $\begin{array}{l}\text { Dictyosphaeria versluysii } \\
\text { (Waikiki, Oahu, Hawaii) }\end{array}$ & driver & $\begin{array}{c}12.3 \\
(+/-0.3)\end{array}$ & $\begin{array}{c}9.8 \\
(+/-0.5)\end{array}$ & $68^{* * *}$ \\
\hline Struvea sp. (outgroup) & driver & & $\begin{array}{c}2.7 \\
(+/-1.2)\end{array}$ & \\
\hline \multicolumn{5}{|c|}{$\begin{array}{l}\text { - Measured thermal midpoint of elution }=77.3^{\circ} \mathrm{C} \\
\text {. Measured renaturation }=51 \% \\
\text { Estimate at the outer limit of sensitivity for the method }\end{array}$} \\
\hline
\end{tabular}




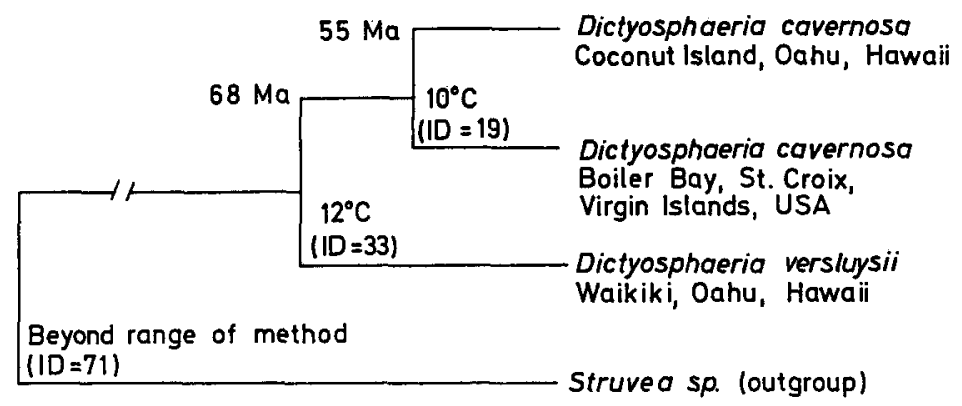

Fig. 2. Phylogenetic hypothesis based on single-copy DNA-DNA hybridization data from Table 2. Topology is identical for both $R B \%$ and $\triangle \operatorname{Tm}(e)$ values. This topology and estimate of divergence also confirms a parallel study based on immunological distance measurements (values in parentheses) (Olsen-Stojkovich et al., 1986)

at the limits of sensitivity of the method. Assignment of real divergence time under a molecular clock model suggests a lineage separation of up to $55 \mathrm{Ma}$ based on a $\triangle \operatorname{Tm}(\mathrm{e})$ value of $10^{\circ} \mathrm{C}$.

\section{DISCUSSION}

The only other benthic macrophytes that have had their nuclear genomes characterized are Cladophora albida [0.48 pg DNA, 3-component complexity, $32 \%$ single-copy (Bot pers. communication)] and Laminaria digitata [0.51 pg DNA, 2-component complexity, $51.43 \%$ single-copy (Stam et al., 1987). Until a data base is generated for many algal groups the significance of any particular genome size and complexity remains obscure.

Assignment of real geological divergence time to phylogenetic topologies is dependent on either a fossil record or knowledge of vicariant events that are hypothesized to have resulted in phyletic radiations. For tropical marine algae, these vicariant events include plate tectonic movements that have opened or closed various bodies of water, especially the Tethys Sea. The Tethys Sea is thought to have extended back at least into the Jurassic (180 Ma ago), during which time a continuous marine flora is believed to have existed (Melville, 1967; Sylvester-Bradley, 1967). With the gradual formation of contemporary continental configurations during the Miocene (ca $20 \mathrm{Ma}$ ago), the Tethys Sea closed and fragmented this primordial marine flora. It is hypothesized that Tethyan remnants have been best preserved in the tropical oceans and that some lineages have continued to evolve, essentially morphologically unchanged, for millions of years. Support for these hypotheses is partly based on limited fossil remains from the Jurassic and Lower Cretaceous (Schopf, 1970; Wray, 1978; Tappan, 1980) and on the living fossil concept (Stanley, 1979; Schopf, 1984) in which extant taxa are morphologically conservative, show little taxonomic diversity, and little provincial endemism. Cladophoralean species fit these criteria.

Other evidence that suggests ancient origins has come from recent protein immunological distance studies among cladophoralean genera and species (Olsen-Stojkovich, 1986; Olsen-Stojkovich et al., 1986). Interspecific distances among five species of Dictyosphaeria were nearly twice as large as those observed among species in the majority of 
other genera in that study; and intraspecific distances among widely separated biogeographic isolates of Dictyosphaeria cavernosa were also inexpectedly large. These results suggested that there were two lineages, morphologically indistinguishable but genetically divergent. This result is further supported by the DNA-DNA hybridization studies reported here in which isolates were collected from the same localities as used in the immunological work.

Most recently, similarly large intraspecific distances have been found in our laboratory in another cladophoralean species, C. albida, using single-copy DNA-DNA hybridizations (Bot et al., unpublished). Isolates from the North Atlantic French coast were compared with isolates from Japan and Australia. All reciprocal comparisons were made. The Australian and Japanese isolates had a $\triangle \operatorname{Tm}(E)$ of $1.5-2.0^{\circ} \mathrm{C}$ between themselves, whereas each had a $\triangle \operatorname{Tm}(e)$ between $5-6{ }^{\circ} \mathrm{C}$ from the European isolate, suggesting a 33Ma divergence.

Single-copy DNA-DNA hybridization studies among five North Atlantic species of Laminaria (Phaeophyceae) show somewhat smaller interspecific distances $(\triangle \operatorname{Tm}(\mathrm{e}) \mathrm{ca}$ $3.0^{\circ} \mathrm{C}$ ) indicating that a species radiation occurred between 15-19 Ma ago (Stam et al., 1987, 1988, in prep.) That study, however, did not investigate intraspecific divergence.

The picture emerging thus far suggests that while Laminaria is a tightly circumscribed genus, whose species are of comparatively more recent origin (15-19 Ma ago), at least some cladophoralean taxa are much older, having evolved as long ago as 55-60 Ma. It is also interesting to ponder how such great genetic divergence could have resulted in so little morphological dissimilarity.

The $D$. cavernosa divergence estimate is, however, offered cautiously for two reasons, one theoretical and one technical. First, this estimate is based on an average rate of sequence change of ca $5.5 \mathrm{Ma} /{ }^{\circ} \mathrm{C} \triangle \operatorname{Tm}(\mathrm{e})$ calculated from a variety of fossil records (Stam et al., 1988, in prep.). A similar divergence estimate based on protein immunological distance data measured by the same techniques and calibrated from fossil pinacean genera (Prager et al., 1976; Price et al., 1987) suggests a divergence time of about $60 \mathrm{Ma}$ for $D$. cavernosa. These estimates are in good agreement. However, since rates have been recently shown to be different for different animal groups (Britten, 1986), it has to be assumed that rates may also differ among plant groups. Unfortunately, similar comparative rate studies for plant groups have not been made. Therefore, these estimates are based on nested assumptions and are crude at best. Second, the data presented here are based on only three isolates and the relative binding of the homologous hybridization was low. Normally, 70-80\% homologous reassociation can be expected. In these experiments, runs that utilized lyophilized material showed good homologous reassociation $(80 \%)$, whereas experiments that utilized frozen material gave a lower percentage $(51 \%)$. This material may have been partially thawed during transport and thus damaged. Despite this, reproducibility of the $10^{\circ} \mathrm{C} \Delta \operatorname{Tm}(\mathrm{e})$ value was good (10\% sequence difference), and corresponds well with a $13.9 \% \mathrm{RB}$ value. Moreover, hybridization with another Hawaiian $D$. cavernosa isolate from Waikiki gave a $\triangle \operatorname{Tm}(e)$ of $0.6{ }^{\circ} \mathrm{C}(=0.6 \%$ difference), indicating virtual identity between the two Hawaiian isolates, which provides an additional check on the hybridization.

In conclusion, although the actual divergence time is subject to some error, the overall result stands that these Dictyosphaeria lineages have been separated for as long as 55-60 Ma as estimated by DNA hybridization data. DNA hybridization studies thus 
provide strong support to the Tethyan vicariance model and raise the question of the species concept in these otherwise morphologically identical taxa.

Acknowledgements. We thank W. van der Hoeven for her invaluable assistance in collecting some of the Hawaiian material. N. Ogden for her assistance with the St. Croix material, and S. Boele-Bos for technical expertise in the laboratory. This research was supported by NATO collaborative grant No. 860702 and grant No. 2250 from The American Philosophical Society. The third author, P. V. M. Bot, was supported by the Foundation for Fundamental Biological Research (BION), which is subsidized by the Netherlands Organization for the Advancement of Pure Research (ZWO).

\section{LITERATURE CITED}

Ayala, F. J., 1986. On the virtues and pitfalls of the molecular evolutionary clock. - J. Hered. 77 , 226-235.

Bonner, T. I., Brenner, D. J., Neufeld, B. R. \& Britten, R. J., 1973. Reduction in the rate of DNA reassociation by sequence divergence. - J. molec. Biol. 81, 123-135.

Britten, R. J., 1986. Rates of DNA sequence evolution differ between taxonomic groups. - Science, N. Y. $231,1393-1398$.

Britten, R. J., Graham, D. E. \& Neufeld, B. R., 1974. Analysis of repeating DNA sequences by reassociation. In: Methods in enzymology, Ed. by S.P. Colowick \& N. O. Kaplan. Acad. Press, New York, 29, 363-416.

Mandel, M. \& Marmur, J., 1968. Use of ultraviolet absorbance temperature profile for determinating the guanine plus cytosine content of DNA. In: Methods in enzymology. Ed. by S. P. Colowick \& N. O. Kaplan. Acad. Press, New York, 12 (B), 195-206.

Melville, R., 1967. The distribution of land around the Tethys Sea and its bearing on modern plant distribution. Syst. Ass. Publ. 7, 291-312.

Olsen-Stojkovich, J., 1986. Phylogenetic studies among genera in the Siphonocladales-Cladophorales complex (Chlorophyta). Ph. D. Diss., Univ. California, Berkeley. 183 pp.

Olsen-Stojkovich, J., West, J. A. \& Lowenstein, J. M., 1986. Phylogenetics and biogeography in the Cladophorales complex (Chlorophyta): Some insights from immunological distance data.-Botanica mar. 29, 239-249.

Prager, E. M., Fowler, D. P. \& Wilson, A. C., 1976. Rates of evolution in conifers (Pinaceae). Evolution 30,637-649.

Price, R. A., Olsen-Stojkovich, J. \& Lowenstein, J. M., 1987. Relationships among the genera of Pinaceae: An immunological comparison. - Syst. Bot. 12, 91-97.

Schopf, J. W., 1970. Pre-Cambrian micro-organisms and evolutionary events prior to the origin of vascular plants. - Biol. Rev. 45, 319-352.

Schopf, T. J. M., 1984. Rates of evolution and the notion of "Living Fossils". - A. Rev. Earth Planet. Sci. $12,245-292$.

Stam, W. T., Bot, P. V. M. \& Hoek, C. van den, 1987. DNA-DNA hybridizations among strains, species and genera of seaweeds: Phylogenetic, biogeographic and taxonomic conclusions. In: 14th International Botanical Congress, Berlin 1987 (Abstracts). Ed, by W. Greuter, B. Zimmer \& H. D. Behnke. Berlin, 358.

Stanley, S. M., 1979. Macroevolution. Freeman, San Francisco, 332 pp.

Sylvester-Bradley, P. C., 1967. The concept of Tethys. - Syst. Ass. Publ. 7, 1-4.

Tappan, H., 1980. The paleobiology of plant protists. Freeman, San Francisco, 1027 pp.

Wilson, A. C., Carlson, S. S. \& White, T. J., 1977. Biochemical evolution. - A. Rev. Biochem. 46, 573-639.

Wray, J. L., 1978. Calcareous algae. In: Introduction to marine micropaleontology. Ed by B. U. Hag \& A. Boersma. Elsevier, New York, $376 \mathrm{pp}$. 